\title{
O acordo afetivo da multidão. O desejo de vingança como princípio do corpo político ${ }^{1}$ \\ Chantal Jaquet
}

Universidade de Paris I - Panthéon Sorbonne

Tradução: Ricardo Mantovani

1 Uma versão mais breve deste texto foi publicada em espanhol com o título de "El deseo (desiderium) de venganza como fundamento del cuerpo político”, Spinoza séptimo coloquio, Diego Tatián (org.), Cordoba, Editorial Brujas, pp. 281-294, 2011.

\section{discurso $45 / 2$}



Preocupado em estabelecer uma política que esteja de acordo, na medida do possível, com a prática, e em deduzi-la da própria condição da natureza humana, Espinosa não alimenta a ilusão de que os homens poderiam viver exclusivamente guiados pela razão. É verdade que os homens são capazes de razão e podem formar ideias adequadas, que seja um mínimo de noções comuns que exprimam as propriedades compartilhadas por todos os corpos, como a extensão, o movimento e o repouso. No entanto, em virtude de seu estatuto ontológico de modos finitos, necessariamente submetidos a causas exteriores que podem lhes ser contrárias, os homens são presas dos afetos passivos, de sorte que frequentemente são tirânicos, cheios de inveja e mais inclinados à vingança do que à piedade. "Por conseguinte, crer que se pode levar a multidão, ou aqueles que são sacudidos para todos os lados, dentro do jogo dos negócios públicos, a viver apenas segundo o preceito da razão, é sonhar com a idade de ouro dos poetas, quer dizer, com uma fábula" (Espinosa, 2005, I, 5).

Tudo isso é bem conhecido, e o autor do Tratado político extrai a consequência que se impõe, tomando os homens tal como eles são e não como se gostaria que fossem. A constituição e a conservação do corpo político não podem, pois, fazer apelo apenas à inteligência dos homens, à sua lealdade ou à sua boa fé, mas exigem uma arte de tirar proveito de suas paixões para constrangê-los a viver tal como se eles fossem razoáveis. Eis por que a sociedade civil e o corpo político não repousam, em primeiro lugar, num acordo fundado sobre a razão, mas sobre um afeto comum. É o que se percebe no $\$ 1$ do capítulo VI do Tratado político: "Porque os homens, como dissemos, são conduzidos pelo afeto mais do que pela razão, segue-se que a multidão entra naturalmente em acordo e quer ser conduzida como que por um só espírito, sob a condução não da razão mas de algum afeto comum: medo comum, esperança comum, ou desejo frustrado de vingar algum dano sofrido em comum (vel desiderio commu- 
ne aliquod damnum ulsciscendi)" (Ibid., VI, 1)².

Se é clássico, desde Hobbes, considerar que um medo coletivo ou uma esperança compartilhada podem estar na origem de um acordo político entre os homens, por outro lado é surpreendente fazer, de uma aspiração a vingar um dano sofrido em comum, um dos princípios possíveis da união e da constituição de um corpo político. É verdade que Espinosa não diz, no $\mathbb{1} 1$ do capítulo VI, que o Estado civil é efetivamente fundado sobre essa aspiração de se vingar de um dano sofrido em comum, somente afirma que a multidão prefere ser conduzida por esse afeto comum - ou por um outro - do que pela razão. Todavia, isso implica que, para pôr a multidão em acordo e fazer reinar a concórdia, o Estado deve levar em conta mais esta paixão do que apenas a razão e valer-se da arte de se utilizar da vingança para que todos, governantes e governados, façam, de bom grado ou à força, o que é necessário à salvação comum.

Portanto, a questão que se impõe é de saber como e por que esse desejo de vingar um prejuízo sofrido em comum pode unir a multidão em corpo e como que por um só espírito. Com efeito, essa via de acordo, aberta no Tratado político, dificilmente parece viável, para não dizermos que é sem saída, pois ela se choca contra um duplo problema, de perenidade e de legitimidade, que põe em xeque a natureza do corpo político e o seu estatuto. Em primeiro lugar, vê-se mal como a multidão poderia ser unida, de maneira duradoura, pela vingança, e como um corpo político estável poderia se constituir sobre tais bases. É verdade que a esperança e o medo são, também eles, afetos flutuantes e inconstantes, que não podem dar uma base absolutamente certa ao corpo político. Mas, se eles podem não dar essa segurança, é possível mantê-los por meio de promessas ou de ameaças e ver o Estado durar, nem que seja por desejo de segurança. Por outro lado, tão logo a ofensa 
é vingada, a razão da união desaparece, e o corpo vingador se dissolve. Em segundo lugar, vê-se mal como o Estado poderia ser um Estado de direito, pois vingança chama vingança, de sorte que um corpo político fundado sobre essa base passional está sob o risco de ser despedaçado por uma violência constante, de ser destruído ou degenerar em tirania.

Toda a questão é, pois, determinar se a aspiração à vingança de um dano sofrido em comum pode, realmente, ser um dos fundamentos passionais do acordo da multidão e servir de meio ao Estado, para assegurar a obediência e garantir os direitos.

\section{A originalidade dessa concepção e as razões de sua introdução}

Antes de responder a esta questão, é preciso sublinhar o caráter original desta hipótese de um acordo da multidão com base em uma aspiração comum à vingança. É verdade que, no que tange aos fatos, não poderia ser questão de conceber um Estado vingador puro e simples. Longe de serem exclusivos, os diferentes motivos que conduzem o homem a aspirar por natureza à sociedade civil se combinam e unem-se sob a forma daquilo que Espinosa chama de medo da solidão, que habita todos os homens em razão de sua incapacidade de se defender e de encontrar os meios de se conservar por si mesmos. A aspiração à sociedade civil não poderia, pois, resumir-se simplesmente ao desejo de vingança; todavia, é bastante notável constatar que ele faz parte dos afetos comuns suscetíveis de unir a multidão num corpo.

Com efeito, essa eventualidade não era considerada no Tra-

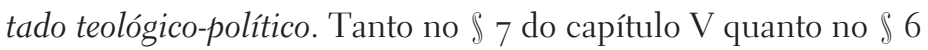
do capítulo XVI, o acordo mútuo, que conduz a fundar o Estado, repousa sobre a utilidade comum e obedece seja a motivos racionais, seja a motivos passionais, como o medo ou a esperança de viver em paz ou de se beneficiar da ajuda de outros para se conservar, mas nenhuma menção é feita a qualquer desejo de vingança. Não se encontra, igualmente, nenhum traço da existência de um móbil vingativo na origem da sociedade política no 
escólio II da proposição XXXVII da Ética IV, consagrado à análise do estado natural e do estado civil. O Tratado político desenvolve, pois, uma via inteiramente nova para pensar a constituição do corpo político.

Poderíamos, então, ser tentados a aproximar esta tese daquela que será desenvolvida por Locke no Segundo tratado sobre o governo civil. Locke admite que cada um, no estado de natureza, se faz justiceiro das ofensas sofridas por outros ou por si mesmo, em virtude da lei natural que prescreve a preservação da humanidade. Cada um, nesse estado, tem o poder de punir as infrações à lei natural na medida de suas forças (Cf. Locke, 1977, II, 7-8). Ora, o gozo desse poder é muito aleatório e comporta riscos de fracasso e de excessos. Assim, uma das três razões pelas quais o homem vai se associar aos outros para formar a sociedade civil é a impotência para punir as ofensas de modo justo. Isto é o que se nota no capítulo IX do Segundo tratado: "os inconvenientes aos quais expõe o exercício irregular e incerto que cada um faz do poder que tem de punir as infrações dos outros incita-os a buscar refúgio no abrigo das leis estabelecidas de um governo e a tentar, assim, salvaguardar sua propriedade. É isto que dispõe cada um a renunciar sem mais ao seu próprio poder de punir aos outros" (Locke, 1977, IX, 126). O Estado se faz, pois, o braço vingador das ofensas não punidas. Contudo, além do fato de sua obra ter sido publicada em 1690 e não ter podido inspirar Espinosa, Locke não visava mostrar que a sociedade política é fundada sobre um desejo de vingança, mas sobre um desejo de justiça, o que não é a mesma coisa.

Espinosa, com efeito, não parte de um desejo de justiça, como se poderia esperar, mas de uma aspiração à vingança. É verdade que no Tratado teológico-político figuram análises das quais se podem encontrar ecos em Locke, pois os homens estabelecem um pacto em que cada um, entre outras coisas, estipula e promete muito firmemente "defender o direito do outro como se fosse o seu” (Espinosa, 1999, XVI, 5, p. 511; G. III, p. 191). Mas, se Espinosa preocupa-se igualmente com a justiça e com a sua aplicação, 
ele a distingue claramente da vingança. Assim como a injustiça, a justiça é um conceito político, que não pode ser conhecido fora de um Estado. Ela designa a vontade constante de atribuir a cada um o que lhe cabe em virtude das decisões do direito comum (Cf. Espinosa, 2005, II, 23). A vingança, por outro lado, é um afeto que pode ser conhecido fora de um Estado, e que pertence ao registro das paixões tristes. Segundo a definição XXXVII da Ética IV, a vingança (vindicta) é "o desejo (cupiditas) que nos excita por ódio recíproco a fazer mal a quem, com igual afeto, nos infligiu um dano". No Tratado político, o acordo da multidão não parte de um desejo de justiça - e por um bom motivo: no estado de natureza não há justiça -, mas de vingança. Portanto, a aproximação com Locke, que admite uma justiça natural, não é nada pertinente. A despeito das aparências, a hipótese de um impulso vingador na origem do Estado não é uma ideia que flutua no ar do tempo. Espinosa abre, pois, uma via original, ao apresentar o desejo de vingança como um princípio de acordo da multidão sobre o qual o Estado pode se fundar, ao lado do medo e da esperança ou de qualquer outro afeto comum².

Podemos, então, nos interrogar sobre as razões dessa inovação e sobre as condições que a tornaram possível. A introdução de um novo motivo passional presidindo o acordo da multidão é consecutiva à mudança do estatuto e do modo de constituição do Estado no Tratado político, que operam um aumento consi-

2 Os comentadores, em geral, nada disseram sobre esse ponto e negligenciaram totalmente este afeto que Espinosa, no entanto, faz questão de citar nominalmente. É verdade que existem outros afetos comuns suscetíveis de unir a multidão em corpo, como a indignação, sobre a qual Alexandre Matheron voltou sua atenção em seu artigo "L’indignation et le conatus de l'État spinoziste", (retomado nos Études sur Spinoza et les philosophies de l'âge classique, ENS, Éditions, 2011, p. 218-229). De qualquer modo, não é a indignação (Indignatio), como ódio por alguém que fez mal a outrem (Cf. Ética, III, definições dos afetos, XX) que é aqui mencionada, mas o desiderium, que é um outro afeto (Cf. Ética, III, definições dos afetos, XXXII) ao qual será necessário que voltemos mais adiante. De resto, isto se explica pelo fato de que, se a indignação que federa a multidão pode dar início a um novo acordo político, ela é evocada por Espinosa, nos $\$ 4$ e $\$ 6$ do capítulo IV, mais para explicar a destruição dos Estados do que para compreender sua instituição e sua conservação. 
derável do papel atribuído aos afetos. O Estado não resulta mais de um contrato como no Tratado teológico-político, mas de uma composição complexa de corpos. Esse novo móbil é revelador de sua própria natureza, de seu princípio de constituição e do modo de ligação dos homens, que entram em acordo para dar forma ao corpo político tomando como base os seus afetos. Bem mais do que aquele que resulta do medo ou da esperança, o acordo nascido do desejo de vingança faz surgir o Estado por aquilo que ele é, a saber, o resultado de uma liga ou de uma conspiração, e não de um contrato. Se o Estado civil tem por origem a vontade de uma multidão desejosa de se vingar, ela não se distingue radicalmente de uma liga suscetível de se dissolver assim que os facciosos estejam satisfeitos. Isto quer dizer, então, que o Estado não é senão uma liga mais poderosa e os cidadãos não são nada além de conspiradores confessos?

Uma tal conclusão não teria nada de escandaloso para Espinosa, pois ele mesmo reivindica esta filiação, mostrando que o acordo da multidão para se unir em sociedade civil obedece aos mesmos motivos que determinam a formação de uma liga. No $\$ 1$ do capítulo VI, com efeito, para explicar a aspiração natural à sociedade civil ligada aos afetos comuns, ele remete expressamente ao artigo 9 do capítulo III, onde está estipulado que "os homens são naturalmente inclinados a se ligar (conspirare), seja em razão [de uma esperança ou] de um medo comum, seja no desejo de se vingar de algum dano sofrido em comum". Os móbiles que presidem o acordo da multidão para formar um corpo vingador e um corpo político são, pois, os mesmos. Espinosa não estabelece, inicialmente, diferença de natureza entre a constituição de um corpo político e aquela de uma conspiração. É verdade que, no \ 9 do capítulo III, trata-se de uma conspiração no interior de uma cidade já constituída, ao passo que, no $\$ 1$ do capítulo VI, trata-se de uma conspiração com vistas a uma cidade que ainda não está constituída. No primeiro caso, a liga se forma contra a cidade e, no segundo, se forma para a cidade. 
No entanto, a liga e a sociedade civil não são de uma essência radicalmente distinta: elas obedecem ao princípio de união e de composição dos corpos que rege toda a física de Espinosa3: corpos que se comprimem e empenham-se em dar uma forma uns aos outros ou que comunicam entre si o mesmo movimento, ou a mesma emoção, se nos colocarmos não mais do ponto de vista físico, mas do mental. Desde então, não é necessário pensar a formação do corpo político sobre outro modelo que não aquele da formação de um corpo qualquer, por composição, e imaginá-lo como um momento solene em que os homens, por contrato, decidem transferir seu direito natural a uma instância superior. O corpo político nasce de uma união de corpos que convergem e confluem sob a pressão de causas exteriores, e que são perpassados pelo mesmo movimento de medo, de esperança ou de sede de vingança que comunicam uns aos outros. Não há, pois, contrato ou compromisso na origem do Estado, mas um concurso de afetos, um movimento de composição sob a pressão de causas exteriores.

Os contratos ou os compromissos não são, assim, nada além de formas verbais ou escritas, exprimindo a comunicação e a conservação do mesmo afeto, e não duram senão enquanto estes afetos perduram, como se pode ver no $\mathbb{\int} 12$ do capítulo II ${ }^{4}$ Espi-

3 Cf. na Ética II a definição de corpos compostos que segue a proposição XIII: "Quando um certo número de corpos, de mesma grandeza ou de grandeza diferente, são pressionados por outros de tal modo a se apoiarem uns sobre os outros, ou, ainda, quando estão em movimento na mesma velocidade ou em velocidade diversa, comunicando uns aos outros seus movimentos segundo uma relação precisa, diremos que estes corpos estão unidos entre si e que, juntos, compõem um só corpo ou Indivíduo, que se distingue de todos os outros por esta união entre corpos".

4 "Um compromisso pelo qual prometemos, de modo puramente verbal, fazer tal e tal coisa que, com direito, poderíamos não fazer - ou inversamente - não continua válido senão enquanto a vontade daquele que se comprometeu não varia. Com efeito, aquele que tem o poder de se desligar de um compromisso na realidade não cedeu seu direito: apenas proferiu palavras. Se, pois, sendo juiz de si por direito de natureza, ele mesmo julgou - com razão ou erroneamente, pois errar é próprio do homem que de um dado compromisso resultará mais prejuízo do que vantagem, é em virtude de uma opinião que lhe é própria que estimará dever se desligar de seu compromisso, e (pelo artigo 9 deste capítulo) se desligará, então, por direito de natureza”. 
nosa dessacraliza, pois, a formação do Estado. Em suma, o corpo político não é um império dentro de um império, ele obedece ao princípio que preside à formação de todos os corpos. O Estado não é senão uma liga que perdura ou que se prolonga através de outros meios. É uma conspiração complexa, que não se distingue de uma simples liga por uma diferença de natureza, mas por uma diferença de grau. Assim, o acordo que resulta da vingança revela a natureza profunda da união da multidão, da qual é o sintoma privilegiado.

Diferentemente das outras associações, no entanto, o corpo político, para Espinosa, jamais se dissolve totalmente. Ele muda de forma, mas nunca é abolido por completo. A razão disso é que os motivos que presidem à sua constituição perduram, malgrado as discórdias e as sedições, pois o medo da solidão continua sendo o mais forte: "ninguém, solitariamente, é suficientemente forte para se defender e para obter tudo aquilo que é necessário à vida, daí se segue que os homens aspiram naturalmente à sociedade civil e que não podem jamais aboli-la completamente" (Espinosa, 2005, VI, 1).

Mas, se o móbil da vingança tem o mérito de destacar a natureza conspiratória do Estado, por outro lado, ele não parece capaz de nos dar a entender a especificidade deste último. Parece, com efeito, incapaz de dar as razões de sua perenidade. Ainda que, quando se trata dos fatos, todos os móbiles estejam combinados, no entanto, é difícil entender como um Estado poderia perdurar com base na vingança e distinguir-se de uma liga temporária. Parece assim que este terceiro meio de pôr os homens em acordo não tem a eficácia dos dois precedentes e é mal adaptado à constituição e manutenção do Estado.

\section{O desejo de vingança: um princípio político problemático}

Construído sobre o modelo de uma liga de vingança, o Estado correria forte risco de ser frágil e ver-se ameaçado por uma avalanche de violências, tanto internas como externas, bem como 
exposto a represálias devastadoras. Ser-lhe-ia necessário, constantemente, reprimir a vingança dos cidadãos e batalhar contra os inimigos. Nestas condições, parece evidente que o uso da aspiração à vingança não é um bom meio para o Estado governar, garantir a paz e a segurança. Como se poderia, pois, conceber a fundação de um acordo político sobre um afeto tão destrutivo?

Se existem paixões boas que podem remediar a fraqueza da razão, a vingança, segundo o próprio Espinosa, delas não faz parte e, desse ponto de vista, os três tipos de afeto passional pelos quais a multidão quer ser conduzida não se situam sobre o mesmo plano. A esperança, com efeito, é uma paixão que aponta a dependência em relação a causas exteriores incertas, mas é um afeto alegre, que aumenta a potência de agir. Segundo a definição XII da Ética III "a esperança (spes) é uma alegria inconstante que nasce de uma ideia de uma coisa futura ou passada de cuja realização temos alguma dúvida". É verdade que a esperança, como lembra a explicação, está sempre misturada ao medo, pois o evento esperado é incerto. Nesse sentido, ela é marcada pela tristeza. Enquanto alegria, no entanto, a esperança possui uma positividade, e Espinosa apresenta-a, preferencialmente, como o motor de uma multidão livre: "uma multidão livre é, com efeito, conduzida pela esperança mais do que pelo medo; uma multidão submissa, mais pelo medo do que pela esperança" (Espinosa, 2005, V, 6).

Se o medo é uma paixão triste e, portanto, menos favorável à potência de agir do que a esperança, ele não é mau em si mesmo. Como o seu contrário, ele é sempre um sentimento misto, pois a tristeza que ele comporta é inconstante e não exclui lampejos de esperança, devido à incerteza do acontecimento. Aliás, Espinosa nunca afirma, expressamente, que o medo é mau. Ele diz que "os afetos de esperança e de medo não podem ser bons por eles mesmos" (Espinosa, 1988, IV, XLVII); admite, pois, que podem sê-lo indiretamente, notadamente quando vêm contrariar uma alegria excessiva (Ibid.). Essa tese será corroborada no escólio da proposição LIV da Ética IV: 
Como os homens vivem raramente sob o ditame da razão, esses dois afetos, a saber, a humildade e o arrependimento, tanto quanto a esperança e o medo, apresentam mais vantagens do que inconvenientes; e, por conseguinte, se for necessário pecar, é preferível que se peque nesse sentido.

E acrescenta, mais abaixo: "a turba é terrível quando está sem medo", o que prova que esse afeto triste pode ter virtudes ao moderar os excessos.

Por outro lado, a vingança jamais pode ser boa, e Espinosa não a inclui dentre os afetos que contêm a turba. Enquanto é animada por um espírito de ódio, a vingança é sempre má. Se o medo e a esperança podem, indiretamente, ser bons, esse não é o caso do ódio. Segundo a proposição XLV da Ética IV “o ódio não pode jamais ser bom”, e Espinosa tem o cuidado de precisar, no corolário I, que "a inveja, a zombaria, o desprezo, a cólera, a vingança, e todos outros afetos que se relacionam com o ódio, ou que dele nascem, são maus". Não se pode ser mais claro, a vingança é má. Assim sendo, é possível perguntar se um Estado não estaria equivocado ao querer explorar o desejo de se vingar.

Antes de mais nada, é preciso notar que Espinosa não leva em conta todas as aspirações particulares à vingança, mas foca somente nas relacionadas a um dano sofrido em comum. Dito de outro modo, ele exclui todo acordo da multidão fundado sobre motivos de vingança pessoal, retendo apenas o caso de um dolo coletivo (como a tentativa de exterminação de uma raça, de exploração ou de despojo de uma classe para o proveito de uma minoria), ou de um dano individual através do qual o conjunto de uma comunidade se encontra ameaçado e lesado. Isso restringe, pois, o campo dos móbiles vingativos que presidem o acordo.

Mas, que a injúria seja ou não comum - e queiramos vingar-nos coletivamente, solitariamente, ou ainda vingar outrem -, em nada altera o caso: a vingança não é boa. Poder-se-ia, assim, aplicar-lhe aquilo que Espinosa diz a propósito da indignação, 
no capítulo XXIV da Ética IV: ela "se dá o ar de uma espécie de equidade; no entanto, vive-se sem lei onde é permitido a cada um realizar julgamentos sobre os atos de outrem, e de vingar seu direito ou mesmo o de outrem, (suum vel alterius jus vindicare licet)". Como aquilo que é a negação da lei poderia dar lugar a leis? Nessas condições, não parece razoável que o Estado se apoie sobre tal princípio. Isto quer dizer que uma tal empreitada seja ilegítima? Tal conclusão seria, no mínimo, apressada, até mesmo errônea, pois o que é mau não é, apenas por isso, ilegítimo.

Com efeito, ocorre com os Estados o mesmo que com os indivíduos humanos. Quer eles sejam regidos pelo desejo cego ou pela razão, perseveram em seu ser por um direito soberano de natureza. Eles agem, pois, sempre de direito, quer dizer, tanto quanto lhes permite sua potência, e, nesse sentido, não há nada de ilegítimo no fato de eles se fundarem sobre o desejo de vingança da multidão. Aliás, Espinosa apresenta, expressamente, a vingança como um direito, notadamente no escólio II da Ética IV, XXXVII: "É pelo soberano direito de natureza que cada um julga o que é bom e mau e vela por seu interesse segundo seu próprio temperamento [...] e se vinga (vindicat)". É verdade que esse direito é mais imaginário do que real, pois cada um só se beneficia de seu próprio direito na exata medida em que tem o poder de repelir as forças contrárias e de vingar como bem entende um dano sofrido, como é dito no $\$ 9$ do Tratado político, II. Há, pois, para cada um, um direito de vingança, que se estende até os limites de sua potência. A constituição de um corpo político não abole esse direito de vingança, mas comunica-o à sociedade. A sociedade, diz Espinosa, no mesmo escólio II da Ética IV, XXXVII, deve "reivindicar para si mesma o direito que cada um tem de se vingar". Como todos os direitos, o direito natural de se vingar não é suprimido, mas conservado no Estado civil, onde o soberano pode usá-lo e exercê-lo como bem entender, dentro dos limites de sua potência. Esse poder de se vingar é, aliás, uma das prerrogativas que manifesta sua autoridade e independência. É, 
notadamente, um dos signos que Espinosa faz valer no Tratado teológico-político para testemunhar o fato de que os Estados dos Países-Baixos continuam soberanos, malgrado haver condes em seu comandos.

É bem verdade que é necessário distinguir o Estado que governa de direito e o melhor Estado, que é instituído segundo o comando da razão, e que dispõe de uma potência superior, como nos indica Espinosa no $\mathbb{1}$ do capítulo V do Tratado político. Desse ponto de vista, um Estado justo, que dá a cada um aquilo que lhe é devido num espírito de equidade e sem ódio é, inegavelmente, superior a um Estado vingador, que pune com crueldade. Daí não se segue que a vingança não seja legítima, como podem sê-lo todas as paixões tristes, na medida em que ela é a expressão do direito natural. É claro, no entanto, que ela não é a marca de uma força de espírito, e que um Estado que nela se apoie mal merece o nome de Estado, pois está no mais baixo grau de sua potência e se assemelha mais a um deserto do que a uma comunidade em paz. Mas isso quer dizer, então, que uma união baseada sobre uma aspiração comum à vingança é própria aos Estados impotentes, e que é necessário substituir, na medida do possível, essa aspiração, na ausência da razão, pelo medo ou pela esperança? A questão que se põe é a de saber como um Estado poderia realmente se fundar sobre um tal afeto e desenvolver uma arte de governar, evitando os reveses ligados ao risco de excesso e de tirania. Dito de outro modo, pode haver, em política, um bom uso da aspiração à vingança?

5 "Quanto aos Estados da Holanda, até onde eu sei, eles jamais tiveram reis. Tiveram somente condes, aos quais o poder de Estado nunca foi transferido. Com efeito, como os próprios Estados soberanos da Holanda tornaram oficial numa apologia publicada à época do conde Leicester, eles sempre se reservaram o direito de chamar os condes a seus deveres e sempre conservaram poder suficiente para defender sua autoridade e a liberdade dos cidadãos, para se vingar dos condes caso estes se tornassem tirânicos, e de contê-los de tal modo que nada pudessem executar sem a autorização e a aprovação dos Estados". (Espinosa, 1999, XVIII, p. 603). 
3. Do bom uso do desejo de vingança: a distinção entre desiderium $e$ cupiditas

Levando-se em conta o modo como apresenta sua intenção, no \1 do capítulo VI do Tratado político, Espinosa parece pender para a afirmativa, pois ele admite, sem dificuldade, que o Estado deve, na impossibilidade de conduzir os homens pela razão, governá-los por um afeto comum qualquer (aliquo affectu). Se ele prefere a esperança ao medo, jamais declara que a aspiração comum à vingança é um móbil de união inferior aos dois outros e que esse afeto não é suscetível de ser bem utilizado. Para compreender verdadeiramente sua tese, é necessário analisar a natureza exata do afeto em questão. Inicialmente, é preciso notar que Espinosa não faz alusão à vingança enquanto tal e nem mesmo a um desejo de vingança, entendido como cupiditas, mas a um desiderium. Os diferentes tradutores, geralmente, traduzem este termo por "desejo", o que oblitera a distinção entre cupiditas e desiderium.

Independentemente de seu objeto, o desiderium é apresentado na Ética como uma espécie de tristeza ligada à ausência de uma coisa que amamos ou que gostaríamos de ter: "Esta tristeza,

6 Este é o caso da tradução de Émile Saisset, revisada por Laurent Bove, que fala de um "desejo de se vingar de algum dano" (Traité politique, traduzido por Émile Saisset, Paris, Livre de poche, 2002, VI, $\$ 1$, p. 164); este é o caso de Madeleine Francès, que menciona, ao lado do medo e da esperança, "o desejo de vingar algum prejuízo sofrido por todos" (Traité de l'autorité politique, traduzido por Madeleine Francès, Paris, Éditions, La Pléiade, Gallimard, p. 952), mas também aquele de Charles Appuhn ou de Pierre-François Moreau, que fazem alusão ao "desejo de se vingar" (Traité politique, traduzido por Charles Appuhn, Paris, GF, 1966, p. 41; Traité politique, traduzido por Pierre-François Moreau, Paris, Éditions Réplique, 1979, VI, \$1, p. 59). Sylvain Zac também se refere a "um desejo comum de se vingar de um dano sofrido" (Traité politique, traduzido por Sylvain Zac, Paris, Vrin, 1968, p. 89). Bernard Pautrat, mais recentemente, menciona, por sua vez, "o desejo comum de vingar algum dano sofrido em comum” (Traité politique, traduzido por Bernard Pautrat, Paris, Éditions Allia, 2013, p. 63). Charles Ramond evita confundir, sob o mesmo vocábulo - desejo (désir) - o desiderium e a cupiditas, e fala da "impaciência de vingar algum dano sofrido em comum", mas o termo impaciência não é muito adequado, e isto por duas razões. De um lado, corre-se o risco de introduzir uma confusão com a passagem do capítulo XIII da Ética IV, onde Espinosa evoca aqueles que criticam os vícios dos homens e que, com a alma impaciente, preferem ir viver com as bestas, e onde ele emprega a expressão animi impatientia, e não a palavra desiderium. Por outro lado, ele oculta o fato de que o desiderium é um afeto que possui uma definição bem precisa em Espinosa. 
enquanto ela concerne à ausência de algo que amamos, se chama desiderium" (Espinosa, 1988, III, XXXVI, Escólio). O termo desiderium é difícil de traduzir e, sem dúvida, a expressão anseio frustrado (souhait frustré), empregada por Charles Appuhn, capta melhor seu espírito do que o termo pesar (regret), empregado por Caillois ou Pautrat. No caso de que tratamos, falar de um anseio ou desejo frustrado de vingança é mais inteligível do que falar de um pesar de vingança, ou então seria necessária uma longa perífrase, e evocar o pesar de não poder se vingar. O desiderium, de fato, implica uma forma de pesar, mas esse termo é muito marcado por uma conotação temporal, ligada ao passado, e não traz, suficientemente, a dimensão do anseio relacionado ao futuro, e ao qual o futuro deu as costas. Espinosa dá uma definição de desiderium mais precisa na Ética III: "Desiderium é o desejo ou apetite de possuir uma coisa, o qual é alimentado pela lembrança dessa coisa e, ao mesmo tempo, é contrariado pela lembrança de outras coisas que excluem a existência da coisa apetecida". Desiderium é, pois, um afeto complexo, que combina três determinações, a lembrança da coisa amada, a lembrança das causas que excluem sua existência e o desejo presente de apossar-se dela e, no futuro, possuí-la. (Cf. Definições dos Afetos, XXXII)

É verdade que o desiderium não é radicalmente diferente da cupiditas; como todo afeto, ele é uma forma de desejo ou de apetite e, por isso, não é totalmente falso falar de um desejo de vingança, como faz a maioria dos tradutores. Entretanto, isso leva a um empobrecimento de sentido e a um risco de erro. Diferentemente da cupiditas em geral, o desiderium exprime a tensão entre a aspiração a uma coisa e os obstáculos que, efetivamente, impedem de realizá-la. Eis por que ele aparece como uma aspiração contrariada ou como um anseio frustrado, que continua à espera de satisfação.

$\mathrm{O}$ fato de que Espinosa evoque um desiderium de vingança de preferência a uma cupiditas não é anódino, e as razões dessa escolha terminológica são perfeitamente lógicas. O desiderium é 
um desejo de possuir ou de apossar-se de uma coisa cuja lembrança é, ao mesmo tempo, viva, como se ela estivesse presente, mas fosse refreada por imagens que excluem sua existência. Aplicado à vingança, o anseio frustrado é o desejo de se fazer pagar por um dano, contrariado pelas causas que excluem sua satisfação. Pode-se compreender, então, que o desiderium, o anseio frustrado de se vingar, conduz os homens a unirem-se e a se associar, pois a associação, ao que parece, realizaria esse projeto e faria desaparecer a representação de causas que a ele se opõem. Se a vingança é má, por outro lado, o desiderium, se não é mau em si mesmo, pode ser bom de modo indireto. Não é necessário, pois, confundir a vingança em si mesma com o desiderium de vingar uma ofensa sofrida em comum. Eis por que é interessante constatar que Espinosa não fala de cupiditas, mas de desiderium. Com efeito, a crermos na definição XXXVII da Ética III, a vingança tomada como cupiditas nos excita, por ódio recíproco, a fazer mal àquele que nos prejudicou. Ela é, por isso, sempre má. Espinosa insiste no fato de que a regra de vida correta é vencer o ódio pelo amor ou pela generosidade, e não compensá-lo com um ódio recíproco. (Espinosa, 1988, IV, XLVI). É por isso que, no escólio da Ética $\mathrm{V}, \mathrm{X}$, ele, para gravar esta regra em nossa memória, preconiza: "pensar nas ofensas que os homens se fazem habitualmente, sobre elas meditar com frequência, assim como na maneira e no meio de rebatê-las ao máximo através da generosidade". Se essa regra de vida é difícil de ser aplicada, é claro, em todo caso, que é necessário se esforçar para renunciar à vingança enquanto desejo em ato, cupiditas, de fazer o mal. "Quem quer se vingar das ofensas por um ódio recíproco vive, com certeza, miseravelmente”. (Ibid., IV, XLVI, Escólio)

Por outro lado, a vingança, enquanto anseio frustrado, não é diretamente boa, mas pode sê-lo indiretamente. O desiderium de vingança é, de certo ponto de vista, o contrário da cupiditas de vingança. Enquanto anseio frustrado, o desiderium implica, com efeito, que o ato vingativo não seja realizado, pois uma determina- 
ção externa vem contrariá-lo, ao passo que a cupiditas implica que tal ato seja realizado, pois uma determinação interna nos impele a cumpri-lo. Lembremos que a cupiditas é "a essência mesma do homem, enquanto concebemo-la como determinada, em virtude de uma afecção sua qualquer, a fazer alguma coisa" (Ibid., III, Definições dos Afetos I7). Devido a um impedimento, o desiderium supõe uma determinação a não realizar a vingança, ao passo que a cupiditas supõe uma determinação a realizar a vingança. Enquanto a ação de fazer mal a outrem não é consumada, o desiderium, contrariamente à cupiditas, continua inofensivo e não pode ser considerado como absolutamente mau.

Não somente ele não é diretamente nocivo como pode ser indiretamente bom, por pelo menos duas razões. De um lado, esse afeto não é apenas um motivo adicional para a união política da multidão e não serve apenas para iniciá-la. Ele é também um poderoso cimento para conservá-la, pois, para poder ser satisfeito, faz com que os homens, com a alma constante, suportem condições de vida rudes e se curvem a penosas regras. O Estado tem, pois, todo interesse em explorá-lo, já que este afeto dá a perseverança na obediência que a inconstância da esperança e do medo não podem sempre garantir de maneira tão eficaz. É o que se depreende do exemplo dado por Espinosa na Ética IV, capítulo XIII: crianças e adolescentes

que não podem suportar, com constância, as reprimendas de seus pais, se refugiam no serviço militar, preferindo os inconvenientes da guerra e a autoridade de um tirano às vantagens domésticas e às admoestações parentais, suportando que lhes seja imposto não importa qual fardo, desde que eles se vinguem de seus pais 8

7 Grifo nosso.

8 Grifo nosso. No seu Discurso sobre a primeira década de Tito Lívio, II, XXVIII, Maquiavel, do mesmo modo, fazia valer o caráter tenaz e contínuo do desejo de vingança, que faz com que tudo seja sacrificado com vistas a ser satisfeito: "Quem é ultrajado profundamente e não recebe a reparação exigida, se vive numa república, procurará 
De outro lado, o desiderium de vingança pode ser indiretamente bom, se utilizado a serviço da justiça. Se é necessário rebater as ofensas com generosidade, isso não implica, no entanto, oferecer a outra face. No capítulo VII do Tratado teológico-político, com efeito, Espinosa insiste no fato de que esse preceito crítico não vale senão para os tempos de repressão, quando é impossível fazer reinar a justiça e quando de nada serve pagar a violência com a violência, pois então haveria consequências mais prejudiciais a cada um do que há na ofensa primeira. Por outro lado, nas cidades de direito, é dever de cada um fazer respeitar a justiça e reclamar a sanção dos prejuízos sofridos.

Este ensinamento do Cristo e de Jeremias - suportar as injustiças e ceder em tudo aos ímpios - não vale senão onde a justiça é negligenciada e nos tempos de opressão, mas não num Estado bem regrado. Muito ao contrário, num Estado bem regrado, onde a justiça é defendida, cada um é obrigado, caso queira ser justo, a exigir reparação diante do juiz pelas injustiças sofridas (Lv. 5: 1): e isso não por vingança (vindictam) (Lv. 19: 17-18), mas com a intenção de defender a justiça e as leis da pátria e para que a maldade não seja vantajosa para os maus. Todas essas coisas concordam perfeitamente com a luz natural (Espinosa, 1999, p. 293).

Se Espinosa considera a vingança como contrária à razão e à justiça, por outro lado o desiderium de vingança pode ser compatível com elas e constituir uma potência auxiliar a seu serviço, na medida em que continua na ordem de um anseio frustrado sem passagem ao ato. Desse ponto de vista, o anseio frustrado de vingar uma ofensa sofrida em comum pode ser a face passional do desejo de justiça e constituir a imitação de uma conduta conforme à ra- 
zão, e pode, nesse sentido, ser um motor e um impulso da justiça. Com efeito, o ato de punir um dano sofrido em comum, ato que deriva do Estado e que constitui a meta visada pela multidão, não tem nada de mau, tomado em si mesmo, pois é a expressão de uma potência e de uma virtude. Nenhuma ação tomada em si mesma é boa ou má, não se tornando uma destas duas coisas senão na proporção dos afetos ativos ou passivos que a determinam, como o demonstra a Ética IV, LIX: “a todas as ações às quais nos determina um afeto que é uma paixão, nós podemos ser determinados sem ele, pela razão". Isso é assim tanto para o ato de punir quanto para o de golpear, ao qual Espinosa se refere no escólio dessa mesma proposição:

A ação de golpear, enquanto consideramo-la fisicamente, e se prestamos atenção somente ao fato de que um homem levanta o braço, fecha a mão e move com força todo seu braço para baixo, é uma virtude, que se concebe pela estrutura do corpo humano. Se, pois, um homem tomado pela cólera ou pelo ódio é determinado a fechar a mão e a mover seu braço, isso ocorre, como mostramos na segunda parte, porque uma só e mesma ação pode estar associada a quaisquer imagens das coisas, e, por conseguinte, podemos ser determinados a uma só e mesma ação tanto por causa de imagens de coisas que concebemos confusamente quanto por imagens de coisas que concebemos clara e distintamente. É evidente, pois, que todo desejo que nasce de um afeto que é uma paixão não teria uso algum, se os homens pudessem ser conduzidos pela razão.

O ato de golpear é um só e mesmo gesto, que é, em cada caso, uma paixão ou uma ação, segundo ele esteja associado à imagem da vingança ou àquela da justiça.

Mas, a partir do momento em que o carrasco atrás do qual se escondem os cidadãos age segundo a lei, pouco importa ao Estado que o ato de punir seja resultado do desejo de justiça ou de um anseio frustrado de vingança. O Estado faz uso de um desejo nascido de um afeto passivo, o desiderium de vingança, para produzir 
um efeito análogo, em ato, àquele de um afeto ativo, o desejo de justiça. Como lembra o escólio, esse anseio frustrado não teria nenhum uso se os homens pudessem ser conduzidos pela razão. Mas este não é o caso. Na ausência do desejo ativo de justiça, é necessário utilizar a forma passional da vingança. Esse desiderium de vingança não tem, pois, nada de mau e, longe de visar perpetuar a frustração, é bom, ao contrário, satisfazê-lo. É o que se depreende do escólio da Ética III, XXXIX: "por bem eu entendo aqui todo tipo de alegria, bem como tudo que para ela contribui, e, principalmente, aquilo que satisfaz o desiderium, seja ele qual for". Não se pode ser mais claro: satisfazer o desiderium, qualquer que seja sua natureza, é um bem.

Em definitivo, um acordo afetivo da multidão baseado no desejo de vingar um dano sofrido em comum pode, sem contradição, resultar na constituição de um corpo político estável, por pouco que compreendamos a natureza do desiderium e desde que não o confundamos com a vingança em ato e seu cortejo de destruição. É desta paixão complexa, tanto quanto do medo e da esperança, que podem nascer o direito coletivo e a justiça, se não puderem ser o produto da razão. Paradoxalmente, a frustração tem uma positividade, pois na medida mesma em que o desejo de se vingar não é cumprido ele pode reunir a multidão em confederação e conduzir à constituição de leis comuns, para a proteção de cada um e a reparação dos danos sofridos. O atual fascínio pelo conceito de indignação, que Espinosa não apresenta jamais como uma virtude em si, não deve, pois, ocultar o papel político maior desse desiderium de vingança, enquanto ele exprime o sofrimento impotente de uma multidão lesada à espera de reparação. O desiderium, definido como tristeza ligada à ausência daquilo que amamos, pode, assim, tornar-se um motor da história e pôr a multidão em marcha em busca de uma satisfação.

Ao introduzir esse novo motivo de união no Tratado político, Espinosa tem por intenção que os afetos tristes sejam aproveitados 
na política, e colocados a serviço de uma potência superior, para a maior alegria de todos.

Referências bibliográficas

ESPINOSA, B. Traité Théologico-Politique. Trad. Jaqueline Lagrée e Pierre-François Moreau. Paris: PUF, 1999. Éthique. Trad. Bernard Pautrat. Paris: Seuil, 1988. Traité Politique. Trad. Charles Ramond. Paris: PUF, 2005.

LOCKE, J. Deux traités du gouvernement civil. Trad. Bernard Gilson. Paris: Vrin, 1977.

MACHIAVEL, N. Discours sur la première décade de Tite-Live. Trad. Toussaint-Guiraudet. Paris: Flammarion, 1985.

. Comentários sobre a primeira década de Tito Lívio. Trad. Sérgio Bath. Brasília: UnB, 2000. Le Prince. Trad. Jean Anglade. Paris: Éditions de Poche, 1972. 